\title{
Analisis Faktor Determinan Return on Asset pada Bank BUMN yang Terdaftar di Bursa Efek Indonesia
}

\author{
Muhammad Shareza Hafiz ${ }^{1)^{*}}$, Radiman ${ }^{2)}$, Maya Sari ${ }^{3)}$, Jufrizen ${ }^{4)}$ \\ $\left.{ }^{1 *}, 2,3,4\right)$ Fakultas Ekonomi dan Bisnis, Universitas Muhammadiyah Sumatera Utara \\ e-mail: mayasari@umsu.ac.id*)
}

\begin{abstract}
This study aims to analyze the effect of Non-Performing Loans (NPL), Capital Adequacy Ratio (CAR), and Loan to Deposit Ratio (LDR), simultaneously on Return on Assets (ROA) on BUMN Banks listed on the Indonesia Stock Exchange either partially and simultaneously.The population used in this study was stateowned Bank companies listed on the Indonesia Stock Exchange (IDX) which amounted to 4 companies. Based on the sample withdrawal criteria above, a research sample of 4 BUMN Bank companies was obtained. Data analysis techniques are used to test the effect of Non-Performing Loans (NPLs), Capital Adequacy Ratio (CAR), and Loan to Deposit Ratio (LDR) to Return on Assets (ROA) either partially or simultaneously is multiple linear regression. The results showed that partially Non Performing Loans (NPL) and Capital Adequacy Ratio (CAR) had a negative and not significant effect on Return on Assets. Partially, Loan to Deposit Ratio (LDR) has a negative and significant effect on Return on Assets. And simultaneously, Non Performing Loans, Capital Adequacy Ratio and Loan to Deposit Ratio have a significant effect on Return on Assets (ROA) at StateOwned Banks listed on the Indonesia Stock Exchange.
\end{abstract}

Keywords: Non Performing Loans, Capital Adequacy Ratio, Loan to Deposit Ratio, Return on Assets

\section{PENDAHULUAN}

Perbankan sebagai lembaga perantara keuangan memiliki fungsi utama sebagai pemasok kredit dari pihak yang memiliki kelebihan dana kepada pihak yang membutuhkan dana. Distribusi kredit yang tepat akan dapat memberikan manfaat bagi Bank berdasarkan perbedaan bunga dengan pinjaman yang diambil. Biasanya, Bank yang mampu meningkatkan pinjaman akan terus meningkatkan laba. Perbankan umumnya menghasilkan pendapatan dengan bunga kredit sebagai sumber pendapatan dalam membiayai operasinya. Bahkan, tidak semua kredit yang dicairkan bebas risiko, karena risiko pembayaran dan kehilangan kredit yang tidak tepat. Dalam Peraturan Bank Indonesia (PBI) nomor 3/1/2011, Bank Indonesia menetapkan tingkat kesehatan Bank Umum yang dapat dinilai dari profil risiko Bank secara inheren dengan kualitas penerapan aplikasi manajemen risiko kredit. Return on Assets (ROA) sangat penting karena Return on Assets (ROA) digunakan untuk mengukur efektivitas Bank dalam menghasilkan laba dengan memanfaatkan aktiva yang dimilikinya. Return on Assets (ROA) merupakan rasio antara laba sesudah pajak terhadap total aktiva. Semakin besar Return on Assets (ROA) menunjukkan kinerja Bank semakin baik, karena tingkat pengembalian 
(return) semakin besar (Husnan, 2009). Return on Assets (ROA) merupakan salah satu indikator penting dari laporan keuangan yang dimiliki dengan berbagai kegunaan. Return on Assets (ROA) digunakan untuk mengukur kemampuan pihak manajemen Bank dalam menghasilkan keuntungan (laba), semakin besar Return on Assets (ROA) suatu Bank semakin besar pula keuntungan yang dicapai Bank tersebut dan semakin baik pula posisi Bank tersebut dari segi penggunaan aktiva. Rasio keuangan yang umumnya mempengaruhi ROA adalah NPL (mewakili risiko kredit), CAR (mewakili modal), serta LDR (mewakili risiko likuiditas).

Kredit macet digambarkan sebagai situasi di mana persetujuan kredit merupakan risiko kegagalan, bahkan cenderung mengarah pada potensi kerugian. Kredit bermasalah atau yang biasa disebut sebagai kreditor bermasalah dapat diukur berdasarkan nilai Non-Performing Loan (NPL) (NPL) dalam persentase. Non-Performing Loan (NPL) merupakan rasio yang membandingkan total kredit macet dengan total kredit yang disalurkan. Non-Performing Loan (NPL) dapat digunakan sebagai indikator risiko kredit, di mana semakin rendah rasio Non-Performing Loan (NPL), semakin rendah tingkat kredit yang terjadi (Ali, 2004). Non-Performing Loan (NPL) menunjukkan kemampuan manajemen Bank dalam mengelola kredit macet yang disediakan oleh Bank, sehingga semakin tinggi Non-Performing Loan (NPL), semakin buruk kualitas kredit Bank yang menyebabkan jumlah kredit macet. Non-Performing Loan (NPL) dapat dipengaruhi oleh tiga yaitu faktor internal Bank, faktor internal hutang atau, dan faktor eksternal non-Bank dan debitur. Faktor internal dapat berupa Capital Adequacy Ratio (CAR), Loan to Deposit Ratio (LDR), Net Interest Margin (NIM), dan Biaya Operasional, sedangkan faktor eksternal Suku Bunga (SBI), dan Ukuran Bank (BS).

Non-Performing Loan (NPL) yang mengalami peningkatan dalam sistem perbankan nasional yang akan mengakibatkan Bank kehilangan kemampuannya untuk menghasilkan laba optimal dari kegiatan utamanya. Dengan meningkatnya kredit macet, pendapatan operasional dari pemberian kredit sangat kecil karena bunga yang harus diterima Bank dari debitur tidak sepenuhnya diterima. Kaaya \& Pastory (2013) menyatakan bahwa, Non-Performing Loan (NPL) yang buruk biasanya menghasilkan provisi pinjaman yang tinggi yang mengarah pada penurunan laba bagi Bank (Kithinji, 2010) dan secara bertahap meminimalkan kemampuan sektor Bank untuk memainkan perannya dalam perkembangan ekonomi (Karim, Chan, and Hassan, 2010).

Untuk meminimalkan risiko masalah kredit, Bank menyediakan dana untuk tujuan pengembangan bisnis dan mengakomodasi risiko kehilangan dana yang disebabkan oleh operasi Bank yang disebut Capital Adequacy Ratio (CAR) (Ali, 2004). CAR adalah rasio kecukupan modal yang berfungsi untuk mengakomodasi risiko kerugian yang mungkin dihadapi Bank (Barus and Erick, 2016). Semakin tinggi Capital Adequacy Ratio (CAR), semakin besar kemampuan Bank untuk meminimalkan risiko kredit yang terjadi, artinya Bank mampu menutupi risiko kredit yang terjadi dengan jumlah cadangan dana yang diperoleh dari perbandingan Aktiva Tertimbang Menurut Resiko (ATMR). Capital Adequacy Ratio (CAR) menjadi modal Bank yang juga menjadi indikator kesehatan Bank berdasarkan peraturan BI No. 13/1 / PBI2011. 
Dalam studi ini, penurunan Non-Performing Loan (NPL) disebabkan oleh meningkatnya kemampuan Bank untuk menanggung risiko kredit atau aset produktif berisiko. Loan to Deposit Ratio (LDR) adalah rasio untuk mengukur komposisi jumlah pinjaman dibandingkan dengan jumlah dana publik dan modal yang digunakan (Kasmir, 2012). Loan to Deposit Ratio (LDR) menyatakan sejauh mana kemampuan Bank untuk membayar kembali penarikan dana para deposan dengan mengandalkan kredit yang diberikan sebagai sumber likuiditas. Semakin tinggi Loan to Deposit Ratio (LDR) Bank, semakin tinggi probabilitas kredibilitas masalah yang akan terjadi karena rasio ini menunjukkan salah satu peringkat likuiditas Bank.

Beberapa penelitian menunjukkan adanya faktor-faktor yang mempengaruhi ROA pada industri perbankan. Hasil penelitian Kusmayadi (2018) serta Winarso dan Salim (2017) menunjukkan bahwa NPL berdampak negatif terhadap ROA. Namun tidak konsisten dengan penelitian Simanjuntak (2016) kesimpulan bahwa NPL memiliki efek positif yang signifikan pada ROA. Selanjutnya penelitian dari Soedarmono et al., (2013) menyimpulkan bahwa CAR tidak berpengaruh signifikan terhadap profitabilitas Bank, sedangkan hasil penelitian Kusmayadi (2018) menemukan bahwa CAR memiliki pengaruh negatif dan signifikan terhadap ROA. Namun, tidak sejalan dengan hasil penelitian sebelumnya Juwita, Raga, Prasetyo, dan Rimawan (2018) yang menemukan bahwa bahwa CAR memiliki pengaruh positif dan signifikan terhadap profitabilitas Bank. Begitu juga penelitian Hapsari (2018) dan penelitian Susilowati dan Tiningrum (2019) yang menyimpulkan adanya pengaruh positif Loan to Deposit Ratio terhadap Return on Asset. Beberapa perbedaan hasil yang terdapat dalam penelitian-penelitian tersebut diatas menunjukkan adanya research gap, sehingga perlu dilakukan kajian penelitian mengenai hubungan antara faktor-faktor tersebut diatas dengan ROA.

Berdasarkan data yang diperoleh dari Bank BUMN yang terdaftar di Bursa Efek Indonesia (BEI), fenomena yang terjadi dalam perusahaan perbankan tersebut adalah Return on Asset (ROA) memiliki rata- rata dari tahun 2014 sampai tahun 2018 mengalami penurunan. Berdasarkan hal ini, peneliti tertarik untuk melakukan penelitian kinerja Bank BUMN di Indonesia Indonesia dengan menggunakan Capital Adequacy Ratio (CAR), Loan to Deposit Ratio (LDR), Non-Performing Loan (NPL) dan Return on Asset (ROA). Tujuan dari penelitian ini adalah untuk mengetahui dampak NonPerforming Loan (NPL) Capital Adequacy Ratio (CAR), dan Loan to Deposit Ratio (LDR) terhadap proksi profitabilitas Bank dengan Return on Asset (ROA).

\section{TINJAUAN PUSTAKA}

\section{Return on Asset (ROA)}

Return on Asset (ROA) adalah indikator seberapa menguntungkan perusahaan relatif terhadap total asetnya. Ini adalah sebuah rasio profitabilitas yang mengukur laba bersih yang dihasilkan oleh total aset selama periode dengan membagi bersih penghasilan dengan total aset rata-rata. ROA memberikan ukuran efisiensi suatu perusahaan dalam mengelola itu aset untuk menghasilkan pendapatan. Rasio ini menunjukkan jumlah laba yang diperoleh relatif terhadap investasi dalam total 
aset (Fraser and Ormiston, 2004). Rasio ini juga memberikan ukuran tingkat efektivitas manajemen suatu perusahaan yang ditunjukkan dari laba yang dihasilkan dari penjualan atau dari pendapatan investasi (Kasmir, 2010). ROA mencerminkan kemampuan Bank manajemen dalam mengelola asetnya untuk menghasilkan laba (Dietrich and Wanzenried, 2010). Besarnya Return on Assets (ROA) dipengaruhi oleh faktor turnover dari operating assets dan profit margin (Munawir, 2018). Adapun alat ukur rasio profitabilitas menurut (Brigham and Houston, 2011) adalah sebagai berikut:

ROA $=\frac{\text { Laba Sebelum Pajak }}{\text { Total Aktiva }}$

\section{Non Performing Loan (NPL)}

Putrianingsih \& Yulianto (2016) menjelaskan bahwa risiko kredit adalah risiko yang terjadi karena pembayaran kembali pinjaman atau pokok pinjaman tidak dapat dilakukan pada saat jatuh tempo. Haneef et al., (2012) menjelaskan bahwa Non-Performing Loan (NPL) merupakan indikator untuk mengukur bagaimana kemampuan Bank untuk mempertahankan tingkat pinjaman kepada konsumen. Yogianta (2013) menjelaskan bahwa NPL menunjukkan rasio pinjaman bermasalah terhadap total pinjaman yang diberikan. Bank tidak hanya diminta memberikan kredit tetapi Bank juga harus melakukan proses review dalam memberikan kredit. Pada dasarnya, kredit macet mencerminkan standar kinerja Bank. Tingkat NPL yang tinggi mencerminkan kemungkinan kerugian dan kekayaan bersih yang tinggi karena jumlah kredit macet yang tinggi dan tingkat NPL yang rendah juga mencerminkan probabilitas laba yang tinggi karena kredit macet yang rendah. (Parul, 2012) menyatakan bahwa pertumbuhan NPL melibatkan perlunya ketentuan karena mengurangi keseluruhan laba dan pemegang saham. Jika ada proporsi tinggi dalam kredit Bank akan ada kemungkinan lebih tinggi bahwa Bank-Bank dapat menderita dari krisis keuangan dan sebaliknya. Rumus rasio ini adalah:

$$
\mathrm{NPL}=\frac{\text { Kredit bermasalah }}{\text { Kredit yang diberikan }} \times 100 \%
$$

\section{Capital Adquacy Ratio (CAR)}

Pinasti \& Mustikawati (2018) menjelaskan bahwa Capital Adequacy Ratio (CAR) adalah rasio keuangan yang terkait dengan modal Bank di mana jumlah modal Bank akan mempengaruhi apakah Bank dapat secara efisien menjalankan kegiatannya. Capital Adequacy Ratio merupakan rasio yang menunjukkan kecukupan modal yang ditetapkan lembaga pengatur yang khusus berlaku bagi industriindustri yang berada dibawah pengawasan pemerintah (Harahap, 2016). Sudarmawanti dan Pramono (2017) mengungkapkan bahwa peningkatan sirkulasi dan penurunan Capital Adequacy Ratio (CAR) akan menunjukkan penurunan aset Bank yang masih dapat ditutupi oleh ekuitas Bank yang tersedia, semakin tinggi CAR, semakin baik kondisi Bank. Capital Adequacy Ratio merupakan rasio permodalan yang merupakan perbandingan antara modal dan Aktiva Tertimbang Menurut Resiko (ATMR). Bobot CAMEL untuk rasio kecukupan modal (Capital Adequacy Ratio) adalah sebesar 12\%. 
Capital Adequacy Ratio memperlihatkan seberapa besar jumlah seluruh aktiva Bank yang mengandung risiko, yang dibiayai dari modal sendiri. Kecukupan modal yang tinggi dan memadai akan meningkatkan volume kredit perbankan. Menurut (Harmono, 2015) dalam menilai capital suatu Bank dapat digunakan Capital Adequacy Ratio dengan rumus:

$\mathrm{CAR}=\frac{\text { Modal }}{\text { Aktiva Tertimbang Menurut Resiko (ATMR) }}$

\section{Loan to Deposit Ratio (LDR)}

Dendawijaya (2009) menjelaskan definisi Loan to Deposit Ratio (LDR) sebagai rasio yang digunakan mengukur tingkat kemampuan Bank untuk membayar kembali penarikan dana yang dilakukan oleh deposan melalui pinjaman yang diberikan sebagai sumber likuiditas Bank. Loan to Deposit Ratio dipergunakan untuk mengukur kemampuan Bank dalam memenuhi permintaan kredit melalui jaminan sejumlah asset yang dimiliki. Loan to Deposit Ratio (LDR) merupakan rasio yang dipergunakan untuk mengetahui kemampuan Bank dalam membayar kepada para penyimpan dana dengan jaminan pinjaman yang diberikan (Jumingan, 2018). Loan to Deposit Ratio merupakan rasio yang digunakan untuk mengukur komposisi jumlah kredit yang diberikan dibandingkan dengan jumlah dana masyarakat dan modal sendiri yang digunakan. Besarnya Loan to Deposit Ratio menurut peraturan pemerintah maksimum adalah $110 \%$ (Kasmir, 2012). Loan to Deposit Ratio tidak luput dari suatu faktor yang mempengaruhi tingkat perubahan rasio yang dihasilkan. Menurut (Veithzal et al., 2013) ada beberapa yang mempengaruhi Loan to Deposit Ratio (LDR) yaitu: 1) kejadian yang jarang terjadi, sifatnya jangka pendek, 2) faktor musiman, 3) faktor-faktor daur usaha, dan 4) kejadiankejadian jangka panjang. Nilai Loan to Deposit Ratio (LDR) dapat ditentukan melalui suatu formula yang ditentukan oleh Bank Indonesia melalui Surat Edaran Bank Indonesia No. 6/23/DPNP Tanggal 31 Mei 2004 yaitu :

$$
\mathrm{LDR}=\frac{\text { Total Kredit }}{\text { Total Dana Pihak Ketiga }}
$$

\section{Kerangka Pemikiran}

\section{Pengaruh Non Performing Loan (NPL) terhadap Return on Asset (ROA).}

Non-Performing Loans (NPL) adalah tingkat kredit macet Bank. Semakin kecil rasio NPL, semakin bijaksana Bank dalam memberikan kredit kepada pelanggan dan ini dengan tujuan mencapai target yang tepat. Ini Praktik membuat pelanggan dan investor percaya bahwa uang yang disimpan di Bank akan dikelola dengan baik dengan demikian, meningkatkan kemampuan Bank untuk menghasilkan laba dengan menggunakan asetnya. Ini berarti Bank proksi profitabilitas oleh ROA juga akan meningkat. Menurut Peraturan No. 15/2 / PBI / 2013 Bank Indonesia, rasio kredit macet (NonPerforming Loan) tidak boleh lebih dari 5\% dari total kredit (Haneef et al., 2012). Hasil penelitian Hakim and Sugianto (2018) menyimpulkan bahwa Non Performing Loan (NPL) memiliki pengaruh 
yang signifikan terhadap Return on Asset (ROA). Hal yang sama dijelaskan oleh Julita (2011); Bhattarai (2016); Pratiwi, Hidayat, and Nasir (2018) serta Kusmayadi (2018) bahwa Non Performing Loans (NPL) memiliki pengaruh negatif yang signifikan terhadap Return on Asset (ROA)

\section{Pengaruh Capital Adequacy Ratio (CAR) terhadap Return on Asset (ROA).}

Menurut Kuncoro dan Suhardjono (2011), rasio kecukupan modal (CAR) adalah kecukupan modal yang menunjukkan kemampuan Bank untuk menjaga kecukupan modal dan manajemen Bank kemampuan untuk mengidentifikasi, mengukur, mengendalikan dan mengendalikan risiko yang dapat memengaruhi jumlah modal Bank. Rumus untuk menghitung CAR adalah modal dibagi dengan aset tertimbang menurut risiko. Menurut peraturan Bank No. 15/12 / PBI / 2013 Di Indonesia, Bank wajib menyediakan modal minimum 8\% dari aset tertimbang menurut risiko (ATMR). Itu meningkatkan rasio CAR berarti bahwa jumlah modal meningkat dan ini menunjukkan bahwa Bank dapat bertahan hidup bahkan jika mereka menderita kerugian. Ini dapat meningkatkan tingkat kepercayaan pelanggan dan investor untuk menyetornya uang. Peningkatan setoran Bank seperti itu dapat berfungsi sebagai dana untuk diberikan sebagai pinjaman Bank dan sebagainya memberikan kontribusi untuk meningkatkan kemampuan Bank untuk menghasilkan laba dengan menggunakan asetnya dan ROA juga akan demikian meningkat. Bernardin (2016) menjelaskan bahwa Capital Adequacy Ratio (CAR) memiliki pengaruh terhadap Return on Asset (ROA). Beberapa penelitian menyatakan bahwa ada pengaruh antara Capital Adequacy Ratio (CAR) terhadap Return on Asset (ROA) (Hantono 2017); (Vernanda and Widyarti 2016); (Anggreni and Suardhika 2014); (Juwita et al. 2018) dan (Simanjuntak 2016).

\section{Pengaruh Loan to Deposit Ratio (LDR) terhadap Return on Asset (ROA).}

Loan to Deposit Ratio (LDR) adalah rasio yang mengukur likuiditas Bank untuk membayar kembali dana yang ditarik oleh pelanggan dalam bentuk tabungan, deposito Bank, dan giro (Kasmir, 2012). Semakin tinggi rasio LDR, semakin tinggi dana yang diberikan kepada pihak ketiga dan ini dapat meningkatkan pengembalian Bank atas aset. Namun, kredit risiko juga meningkat karena jumlah dana yang dibutuhkan untuk membiayai kredit semakin besar (Alhaq, Taufeni and Desmiyanti, 2012). Peraturan No. 15/41 / DKMP tanggal 1 Oktober 2013 tentang Bank Indonesia menyatakan bahwa batas pinjaman to deposit ratio Bank minimum 78\% dan maksimum 92\%. Rumus untuk menghitung LDR adalah kredit yang diberikan dibagi dengan total setoran dari pihak ketiga. Semakin tinggi LDR semakin tinggi tingkat perusahaan keuntungan karena penempatan dana dalam bentuk kredit yang diberikan demikian, pendapatan bunga akan meningkat. Ini dapat meningkatkan kemampuan Bank untuk menghasilkan laba dengan menggunakan asetnya, sehingga ROA akan meningkat. Soares and Yunanto (2018) menunjukkan bahwa Loan to Deposit Ratio (LDR) memiliki implikasi untuk profitabilitas yang diproksi dengan Return on Asset (ROA). Penelitian yang dilakukan oleh Muttaqin (2017); Zulfachri (2017); Hapsari (2018); Susilowati and Tiningrum (2019) serta Azmy (2018) 
menyimpulkan bahwa Loan to Deposit Ratio (LDR) memiliki pengaruh yang signifikan terhadap Return on Asset (ROA).

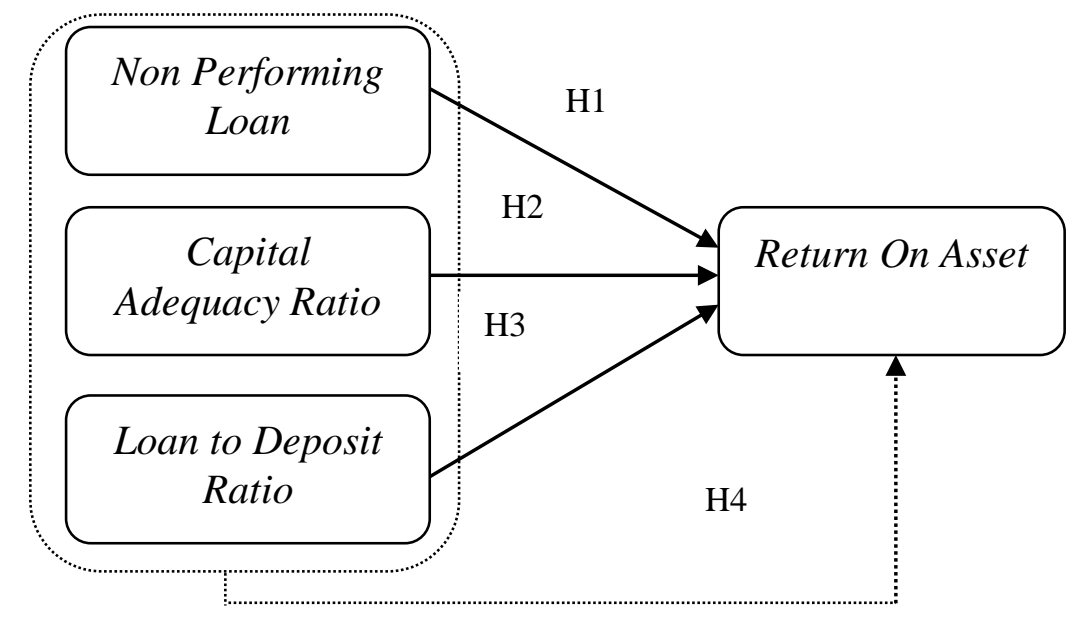

\section{Gambar 1. Kerangka Pemikiran}

\section{Hipotesis Penelitian}

Berdasarkan kerangka pemikiran maka hipotesis penelitian ini adalah:

1. Non Performing Loan (NPL) berpengaruh terhadap Return on Asset (ROA) pada Bank BUMN yang terdaftar di Bursa Efek Indonesia.

2. Capital Adequacy Ratio (CAR) berpengaruh terhadap Return on Asset (ROA) pada Bank BUMN yang terdaftar di Bursa Efek Indonesia.

3. Loan to Deposit Ratio (LDR) berpengaruh terhadap Return on Asset (ROA) pada Bank BUMN yang terdaftar di Bursa Efek Indonesia.

3. Non Performing Loan (NPL), Capital Adequacy Ratio (CAR), Loan to Deposit Ratio (LDR), Capital Adequacy Ratio (CAR) berpengaruh terhadap Return on Asset (ROA) pada Bank BUMN yang terdaftar di Bursa Efek Indonesia.

\section{METODE PENELITIAN}

Pendekatan penelitian yang digunakan adalah menggunakan pendekatan asosiatif. Penelitian ini dilakukan di Bursa Efek Indonesia (BEI) khusus Bank BUMN yang terdaftar di Bursa Efek Indonesia (BEI) periode 2014 sampai dengan 2018 dengan mengumpulkan data laporan keuangan yang tersedia disitus resmi www.idx.co.id.

1. Return on Asset (ROA)

Return on Asset merupakan rasio perbandingan laba sebelum pajak dengan total aktiva yang didapat dari laporan keuangan neraca dan laporan keuangan laba rugi.

2. Non Performing Loan (NPL)

Non-Performing Loan (NPL) merupakan indikator untuk mengukur bagaimana kemampuan Bank untuk mempertahankan tingkat pinjaman kepada konsumen. 
3. Capital Adequacy Ratio (CAR)

Capital Adequacy Ratio merupakan rasio yang menunjukkan kecukupan modal yang ditetapkan lembaga pengatur yang khusus berlaku bagi industri-industri yang berada dibawah pengawasan pemerintah.

4. Loan to Deposit Ratio (LDR)

Loan to Deposit Ratio merupakan rasio yang digunakan untuk mengukur komposisi jumlah kredit yang diberikan dibandingkan dengan jumlah dana masyarakat dan modal sendiri yang digunakan.

Sumber data penelitian ini adalah data sekunder yang diperoleh dari Bank BUMN yang terdaftar di Bursa Efek Indonesia. Untuk memperoleh data yang diperlukan, digunakan teknik dokumentasi dari data yang dipublikasikan dari situs resmi Bursa Efek Indonesia (BEI) www.idx.co.id. Populasi penelitian ini adalah perusahaan Bank BUMN yang terdaftar di Bursa Efek Indonesia (BEI) pada tahun 2014-2018 yang berjumlah 4 perusahaan. Dalam penelitian ini, penulis menggunakan teknik purposive sampling yaitu metode penarikan sampel berdasarkan kepada kriteria tertentu. Kriteria pengambilan sampel yang ditetapkan dalam penelitian ini adalah sebagai berikut:

1. Perusahaan Bank BUMN yang terdaftar di Bursa Efek Indonesia (BEI) dalam kurun waktu penelitian (periode 2014-2018).

2. Tersedianya laporan keuangan selama kurun waktu penelitian (periode 2014-2018).

Berdasarkan kriteria penarikan sampel, maka diperoleh sampelpenelitian sebanyak 4 perusahaan Bank BUMN. Adapun sample penelitian tersebut adalah sebagai berikut:

Tabel 1. SAmpel Perusahaan Bank BUMN di Bursa Efek Indonesia

Periode 2014-2018

\begin{tabular}{ccc}
\hline NO & KODE EMITEN & NAMA PERBANKAN \\
\hline 1 & BBRI & PT. Bank Rakyat Indonesia, Tbk. \\
2 & BBNI & PT. Bank Negara Indonesia, Tbk. \\
3 & BMRI & PT. Bank Mandiri, Tbk \\
4 & BBTN & PT. Bank Tabungan Negara, Tbk \\
\hline
\end{tabular}

Teknik analisis data yang digunakan untuk menguji pengaruh Non Performing Loan (NPL), Capital Adequacy Ratio (CAR), dan Loan to Deposit Ratio (LDR) terhadap Return on Asset (ROA) baik secara parsial atau simultan adalah regresi linier berganda.

\section{HASIL DAN PEMBAHASAN}

Sebelum melakukan analisis terhadap pengujian hipotesis, diperlukan uji asumsi klasik untuk menghasilkan suatu model data yang baik. Ada 4 (empat) uji asumsi klasik yang harus dipenuhi yaitu uji normalitas, uji multikolinieritas, uji heterokedastisitas dan uji autokorelasi. Berikut ini merupakan pengujian terhadap uji asumsi klasik, apakah keempat uji asumsi klasik tersebut terpenuhi atau tidak.

1. Uji Normalitas

Uji normalitas bertujuan untuk melihat apakah dalam model regresi, variabel dependen dan 
independen memiliki distribusi normal atau tidak. Jika data menyebar di sekitar garis diagonal dan mengikuti arah garis diagonal maka model regresi memenuhi asumsi normalitas (Juliandi, Irfan dan Manurung, 2015). Hasil pengujian menunjukkan bahwa adanya pola grafik yang normal dimana titik-titik berada tidak jauh dari garis diagonal, hal ini berarti bahwa model regresi tersebut sudah berdistribusi normal. Begitu juga dengan pengujian normalitas dengan uji KolmogorovSmirnov, diperoleh besarnya nilai Kolmogorov-Smirnov adalah 1,105 dan signifikansi pada 0.174. Nilai signifikansi ternyata lebih besar dari 0.05 maka $\mathrm{H}_{0}$ diterima yang berarti data residual tersebut berdistribusi normal

2. Uji Multikolinieritas

Uji multikolinieritas bertujuan untuk menguji apakah pada model regresi ditemukan adanya korelasi yang kuat antar variabel independent. Cara yang digunakan untuk menilainya adalah dengan melihat nilai faktor inflasi varian (variance inflasi factor/VIF), yang tidak melebihi 4 atau 5,(Juliandi, Irfan dan Manurung, 2015). Hasil pengujian menunjukkan bahwa semua variabel yang digunakan sebagai prediktor model regresi menunjukkan nilai VIF yang cukup kecil, dimana semuanya berada di bawah 10 dan nilai tollerance lebih dari 0,1. Hal ini berarti bahwa variabel bebas yang digunakan dalam penelitian tidak menunjukkan adanya gejala multikolinieritas.

\section{Uji Heteroskedastisitas}

Uji Heteroskedastisitas bertujuan untuk menguji apakah terjadi ketidaksamaan varians residual dari suatu pengamatan yang lain. Deteksi heteroskedastisitas dapat dilakukan dengan metode scatter plot dengan memplotkan nilai ZPRED (nilai prediksi) dengan SRESID (nilai residualnya) (Juliandi, Irfan dan Manurung, 2015). Hasil pengujian heteroskedastisitas menunjukkan bahwa tidak ada pola yang jelas dan titik-titik menyebar secara acak serta tersebar, baik diatas maupun dibawah angka 0 pada sumbu Y. Hal ini mengindikasikan bahwa tidak terjadi heterokedastisitas pada model regresi sehingga model regresi layak dipakai untuk memprediksi Return On Asset.

4. Uji Autokolerasi

Uji autokorelasi bertujuan untuk menguji model regresi liniear ada korelasi antara kesalahan pengganggu pada periode t dengan kesalahan pengganggu pada periode t-1 (sebelumnya). Hasil pengujian menunjukkan bahwa nilai perolehan Durbin Watson (D-W) sebesar 1,830 yang berarti -2 $<1,830<2$. Maka dapat disimpulkan bahwa dari angka Durbin Watson tersebut tidak terjadi autokorelasi.

\section{Pengujian Hipotesis}

\section{Uji Secara Parsial (Uji t)}

Uji statistik t dilakukan untuk menguji apakah variabel bebas bebas (X) secara parsial mempunyai hubungan yang signifikan atau tidak terhadap variabel terikat (Y). Untuk penyerderhanaan uji t dengan menggunakan pengolahan data SPSS for windows versi 20.00, diperoleh hasil uji t sebagai berikut: 
Tabel 2. Hasil Analisis Statistik

\begin{tabular}{|c|c|c|c|c|}
\hline Variabel & & B & $\mathrm{t}$ & Sig. $t$ \\
\hline Konstanta & & 7,676 & 3,688 & 0,000 \\
\hline LDR & & $-0,037$ & $-1,257$ & 0,212 \\
\hline CAR & & $-0,007$ & $-0,158$ & 0,875 \\
\hline NPL & & $-1,478$ & $-4,298$ & 0,000 \\
\hline Adjusted R. Square & $=$ & 0.200 & & \\
\hline $\mathrm{F}$ & $=$ & 7.601 & & \\
\hline Sig. F & $=$ & 0.000 & & \\
\hline
\end{tabular}

Sumber: Data diolah, 2019

Berdasarkan hasil pengujian secara parsial pengaruh antara Non Performing Loan (NPL) terhadap Return on Asset (ROA) nilai thitung untuk variabel Non Performing Loan (NPL) adalah -1,257dan $t_{\text {tabel }}$ adalah -1,995 dengan nilai sig 0,212 lebih besar dari 0,05. Dengan demikian $t_{\text {hitung }}$ diperoleh -1,257 >-1,995 dengan kesalahan 5\% dan tingkat kepercayaan 95\%, maka hasil ini dapat disimpulkan bahwa $\mathrm{H}_{0}$ diterima dan $\mathrm{H}_{\mathrm{a}}$ ditolak.

Berdasarkan hasil pengujian secara parsial pengaruh antara Capital Adequacy Ratio (CAR)terhadap Return on Asset (ROA) nilai thitung untuk variabel Capital Adequacy Ratio (CAR) adalah -0,158 dan $t_{\text {tabel }}$ diketahui -1,995 dengan nilai sig 0,875 lebih besar dari 0,05. Dengan demikian $t_{\text {hitung }}$ diperoleh-0,158>-1,995 (lebih besar dari $t_{\text {tabel }}$ ) dengan kesalahan sebesar 5\% dan tingkat kepercayaan 95\% maka dari itu dapat disimpulkan bahwa $\mathrm{H}_{0}$ diterima dan $\mathrm{H}_{\mathrm{a}}$ ditolak.

Berdasarkan hasil pengujian secara parsial pengaruh antara Loan to Deposit Ratio (LDR) terhadap Return on Asset (ROA) nilai thitung untuk variabel Loan to Deposit Ratio (LDR) adalah -4,298

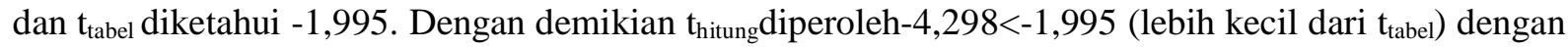
kesalahan sebesar 5\% dan tingkat kepercayaan 95\% dan maka dari itu dapat disimpulkan bahwa $\mathrm{H}_{0}$ ditolak dan $\mathrm{H}_{\mathrm{a}}$ diterima.

\section{Uji Simultan Signifikan (Uji F)}

Uji statistik F dilakukan untuk menguji apakah variabel bebas (X) secara simultan mempunyai hubungan yang signifikan atau tidak terhadap variabel terikat (Y). Dari Tabbel 2 dapat dilihat nilai F-hitung sebesar 7,601 dengan tingkat signifikansi sebesar 0.000 (lebih kecil dari 0.05). Sedangkan F-tabel diketahui sebesar 2,87. Berdasarkan hasil tersebut dapat diketahui bahwa $F_{\text {hitung }}>F_{\text {tabel }}$ $(7,601>3,13) \mathrm{H}_{0}$ ditolak dan $\mathrm{H}_{\mathrm{a}}$ diterima. Jadi dapat disimpulkan bahwa variabel Non Performing Loan, Capital Adequacy Ratio dan Loan to Deposit Ratio secara bersama-sama terdapat pengaruh yang signifikan terhadap Return on Asset pada Bank BUMN yang terdaftar di Bursa Efek Indonesia.

\section{Koefisien Determinasi}

Koefisien determinasi ini berfungsi untuk mengetahui persentase besarnya pengaruh variabel independen dan variabel dependen yaitu dengan mengkuadratkan koefisien yang ditemukan. Pada Tabel 2, dapat dilihat hasil analisis regresi secara keseluruhan menunjukkan nilai $\mathrm{R}$ sebesar 0.480 
sedangkan besarnya nilai Adjusted Square $\left(\mathrm{R}^{2}\right)$ atau koefisien determinasi adalah sebesar 0.200. Angka ini mengidentifikasikan bahwa Return on Asset (variabel dependen) mampu dijelaskan oleh Non Performing Loan, Capital Adequacy Ratio dan Loan to Deposit Ratio (variabel independen) sebesar $20 \%$, sedangkan selebihnya sebesar $80 \%$ dijelaskan oleh factor-faktor lain yang tidak diteliti dalam penelitian ini.

\section{Pembahasan}

\section{Pengaruh Non Performing Loan (NPL) Terhadap Return on Asset (ROA)}

Hasil pengujian secara parsial mengenai pengaruh Non Performing Loan (NPL) terhadap Return on Asset pada Bank BUMN yang terdaftar di Bursa Efek Indonesia, menunjukkan bahwa nilai $\mathrm{t}_{\text {hitung }}$ untuk variabel Non Performing Loan (NPL) adalah -1,257>-1,995 dan nilai signifikansi sebesar 0,212 (lebih besar dari 0,05). Hal ini menunjukkan bahwa secara parsial Non Performing Loan (NPL) berpengaruh negative dan tidak signifikan terhadap Return on Asset pada Bank BUMN yang terdaftar di Bursa Efek Indonesia. Berdasarkan hasil analisis memberi makna semakin tinggi Non- Performing Loan akan berdampak pada menurunnya kemampuan Bank dalam menciptakan Return on Asset. Meningkatnya Non Performing Loan memberikan ilustrasi yang berkualitas aset produktif Bank menurun atau yang lain kata-kata kredit semakin bermasalah. Keadaan ini maka profitabilitas Bank akan terganggu. Temuan penelitian ini konsisten dengan yang sebelumnya yaitu Usman (2003), Soedarmono et al. (2013), Latifah, Rodhiyah, dan Saryadi (2012), Julita (2011), Paramarta dan Suardani (2014), Pratiwi et al. (2018), Kusmayadi (2018) dan Winarso and Salim (2017) yang menyatakan bahwa NPL berdampak negatif terhadap ROA. Namun tidak konsisten dengan penelitian sebelumnya yaitu Aini (2013) dan Simanjuntak (2016) dimana NPL memiliki efek positif yang signifikan pada ROA.

\section{Pengaruh Capital Adequacy Ratio (CAR) Terhadap Return on Asset(ROA)}

Hasil pengujian secara parsial mengenai pengaruh antara Capital Adequacy Ratio (CAR) terhadap Return on Asset (ROA) nilai thitung untuk variabel Capital Adequacy Ratio (CAR) -0,158 > -1,995 dan nilai signifikansi sebesar 0,875 (lebih besar dari 0,05). Berdasarkan hasil tersebut menunjukan bahwa secara parsial variabel Capital Adequacy Ratio (CAR) berpengaruh negative dan tidak signifikan terhadap Return on Asset (ROA) pada Bank BUMN yang terdaftar di Bursa Efek Indonesia. Berdasarkan hasil analisis memberi makna bahwa Modal lebih tinggi Rasio Kecukupan tidak dapat berkontribusi secara proporsional dalam meningkatkan Return on Asset. CAR tinggi akan memberikan kemampuan bagi Bank untuk menanggung risiko kredit dan keuangan kegiatan operasional bahkan dapat berdampak pada penciptaan profitabilitas jika sejalan dengan pertumbuhan kualitas aset produktif dan kredit yang sehat. Ini kondisi tidak konsisten dengan kondisi yang terjadi di BPR di Indonesia meskipun dilihat dari CAR lebih tinggi tetapi di sisi lain ada penurunan Tren ROA. Ini dianggap sebagai dampak dari pertumbuhan pinjaman atau ekspansi kredit yang lebih lambat, 
semakin tinggi risiko kredit diwakili oleh menurunnya kualitas produktif aset, suku bunga, faktor persaingan, regulasi, dan faktor lain. Temuan penelitian ini konsisten dengan penelitian sebelumnya dari Soedarmono et al. (2013) bahwa CAR tidak berpengaruh signifikan terhadap profitabilitas Bank, Christaria and Kurnia (2016) dan Kusmayadi (2018) menemukan bahwa CAR memiliki efek negatif signifikan terhadap ROA. Namun, tidak konsisten dengan hasil penelitian sebelumnya yaitu (Aini (2013), Simanjuntak (2016) dan Juwita et al. (2018) bahwa CAR memiliki nilai positif dan dampak signifikan terhadap profitabilitas Bank.

\section{Pengaruh Loan to Deposit Ratio (LDR)Terhadap Return on Asset (ROA)}

Hasil pengujian secara parsial mengenai pengaruh antara Loan to Deposit Ratio (LDR) terhadap Return on Asset (ROA) nilai thitung untuk variabel Loan to Deposit Ratio (LDR) adalah - 4,298 $<-1,995$ (lebih kecil dari $t_{\text {tabel}}$ ) dengan kesalahan sebesar 5\% dan tingkat kepercayaan 95\%. Berdasarkan hasil tersebut menunjukan bahwa secara parsial variabel Loan to Deposit Ratio (LDR) memiliki pengaruh dan signifikan negatif terhadap Return on Asset (ROA) pada Bank BUMN yang terdaftar di Bursa Efek Indonesia. Hasil tersebut menunjukkan bahwa secara parsial variabel Loan to Deposit Ratio (LDR)memiliki pengaruh dan signifikan negatif terhadap Return on Asset (ROA) pada Bank BUMN yang terdaftar di Bursa Efek Indonesia. Berdasarkan hasil analisis, berarti aspek likuiditas atau kemampuan entitas untuk menyediakan dana untuk memenuhi jatuh tempo kewajiban yang ditekan dengan Pinjaman kepada Setoran dikendalikan dan tumbuh sejalan secara proporsional dengan pertumbuhan Return on Asset. Loan to Deposit Ratio juga tinggi menunjukkan ekspansi kredit yang agresif sehingga dengan kualitas aset yang dikendalikan, Bank akan dapat menciptakan keuntungan, tetapi di sisi lain, akan mengganggu likuiditas Bank dalam hal penarikan dana oleh pelanggan. Rasio Pinjaman terhadap Deposit yang Rendah akan menyebabkan kelebihan likuiditas sehingga dimungkinkan dana menganggur karena dana tidak disalurkan yang mempengaruhi penurunan kemampuan Bank dalam menciptakan profitabilitas. Temuan dari penelitian ini konsisten dengan penelitian sebelumnya dari Paramarta and Suardani (2014), Irmawati dan Sari (2014), Hantono (2017), Simanjuntak (2016), Zulfachri 2017), Hapsari (2018), Susilowati dan Tiningrum (2019) serta Azmy, Febriansyah, and Munir (2019) yang menyimpulkan adanya pengaruh positif di antara keduanya Loan to Deposit Ratio terhadap Return on Asset.

\section{Pengaruh Non Performing Loan, Capital Adequacy Ratio dan Loan to Deposit Ratio Terhadap Return on Asset}

Hasil pengujian secara simultan mengenai pengaruh Non Performing Loan (NPL), Capital Adequacy Ratio (CAR) dan Loan to Deposit Ratio (LDR) terhadap Return on Asset (ROA) pada Bank BUMN yang terdaftar di Bursa Efek Indonesia. Dari uji ANOVA(Analysis Of Variance) pada tabel 2 sebelumnya didapat F hitung sebesar $7.601>3,13$ dengan tingkat signifikansi sebesar 0.000. Hal ini berarti bahwa Non Performing Loan (NPL), Capital Adequacy Ratio (CAR) dan Loan to Deposit 
Ratio (LDR) memiliki kontribusi terhadap Return on Asset (ROA).Maka dapat disimpulkan bahwa terdapat hubungan signifikan secara simultan antara Non Performing Loan (NPL), Capital Adequacy Ratio (CAR) dan Loan to Deposit Ratio (LDR) memiliki kontribusi terhadap Return on Asset (ROA) pada Bank BUMN yang terdaftar di Bursa Efek Indonesia.

\section{KESIMPULAN DAN SARAN}

Berdasarkan hasil penelitian dan pembahasan, maka kesimpulan dari penelitian mengenai Pengaruh Non Performing Loan (NPL), Capital Adequacy Ratio (CAR) dan Loan to Deposit Ratio (LDR) terhadap Return on Asset pada Bank BUMN yang terdaftar di Bursa Efek Indonesia, pertama secara parsial Non Performing Loan (NPL) berpengaruh negatif dan tidak signifikan tehadap Return on Asset pada Bank BUMN yang terdaftar di Bursa Efek Indonesia. Kedua, secara parsial Capital Adequacy Ratio (CAR) berpengaruh negatif dan tidak signifikan terhadap Return on Asset pada Bank BUMN yang terdaftar di Bursa Efek Indonesia. Ketiga secara parsial Loan to Deposit Ratio (LDR) berpengaruh negatif dan signifikan tehadap Return on Asset pada Bank BUMN yang terdaftar di Bursa Efek Indonesia. Keempat, secara simultan Non Performing Loan, Capital Adequacy Ratio dan Loan to Deposit Ratio berpengaruh signifikan terhadap Return on Asset (ROA) pada Bank BUMN yang terdaftar di Bursa Efek Indonesia.

Berdasarkan kesimpulan diatas, maka dapat diberikan beberapa saran bagi perBankan diharapkan mampu menjaga keseimbangan rasio keuangan CAR, NPL dan LDR agar tetap terjaga sesuai dengan Peraturan yang telah ditetapkan oleh Bank Indonesia. PerBankan juga harus menjaga sistemnya agar NPL dapat ditekan, karena apabila NPL menurun maka otomatis ROA pada Bank tersebut akan naik. Sebaliknya apabila dalam suatu perBankan NPL nya meningkat, maka ROA pada Bank tersebut akan menurun. Bagi Investor dapat memilih saham mana yang akan dibeli untuk memperoleh hasil yang lebih besar. Penelitian ini memiliki keterbatasan sehingga penelitian selanjutnya disarankan untuk memperluas penelitian objek tidak hanya terbatas pada Bank yang terdaftar di Bursa Efek tetapi juga semua domestik dan Bank asing yang berada di Indonesia. Kemudian, penelitian selanjutnya disarankan untuk menambahkan lainnya variabel seperti BOPO dan NIM.

\section{REFERENSI}

Aini, Nur. 2013. Pengaruh CAR, NIM, LDR, NPL, BOPO, dan Kualitas Aktiva Produktif terhadap Perubahan Laba (Studi Empiris pada Perusahaan Perbankan yang Terdaftar di BEI) Tahun 20092011. Dinamika Akuntansi, Keuangan Dan PerBankan. Vol. 2 No. 1. Hal: 14-25.

Alhaq, Muhammad, Taufik Taufeni, dan Desmiyanti. 2012. Pengaruh Capital Adequacy Ratio, Kualitas Aktiva Produktif, Non Performing Loan, dan Loan to Deposit Ratio terhadap Profitabilitas Perusahaan Perbankan yang Terdaftar di Bursa Efek Indonesia Periode 2008-2010. Fakultas Ekonomi. Universitas Riau.

Ali, Masyhud. 2004. Asset Liability Management, Menyiasati Risiko Pasar dan Risiko Operasional dalam PerBankan. Jakarta: PT Elek Media Komputindo.

Anggreni, Made Ria dan Made Sadha Suardhika. 2014. Pengaruh Dana Pihak Ketiga, Kecukupan 
Modal, Risiko Kredit dan Suku Bunga Kredit terhadap Profitabilitas Bank BUMN Tahun 20102012. E-Jurnal Akuntansi. Vol. 9 No. 1. Hal: 27-38.

Azmy, Ahmad. 2018. Analisis Pengaruh Rasio Kinerja Keuangan terhadap Profitabilitas Bank Pembiayaan Rakyat Syariah di Indonesia. Jurnal Akuntansi. Vol. 22 No. 1. Hal:119-137.

Azmy, Ahmad, Iqbal Febriansyah, dan Anita Munir. 2019. The Effect of Financial Performance Ratios on Conventional Bank Profitability in Indonesia Stock Exchange. Ekuilibrium: Jurnal Ilmiah Bidang Ilmu Ekonomi. Vol. 14 No. 2. Hal: 84-103.

Barus, Andreani Caroline dan Erick Erick. 2016. Analisis Faktor-Faktor yang Mempengaruhi Non Performing Loan pada Bank Umum di Indonesia. Jurnal Wira Ekonomi Mikroskil. Vol. 6 No. 2. Hal: 113-22.

Bernardin, Deden Edwar Yokeu. 2016. Pengaruh CAR dan LDR terhadap Return on Assets. Ecodemica. Vol. 4 No. 2. Hal: 232-41.

Bhattarai, Yuga Raj. 2016. Effect of Non-Performing Loan on the Profitability of Commercial Banks in Nepal. The International Journal Of Business \& Management. Vol. 4 No. 6. Hal: 435-442.

Brigham, Eugene F. dan Joel F. Houston. 2011. Dasar-Dasar Manajemen Keuangan. Jakarta: PT. Salemba Empat.

Christaria, Fiola dan Ratnawati Kurnia. 2016. The Impact of Financial Ratios, Operational Efficiency and Non- Performing Loan Towards Commercial Bank Profitability. Accounting and Finance Review. Vol. 1 No. 1. Hal: 43-50.

Dendawijaya, Lukman. 2009. Manajemen PerBankan. Bogor: Ghalia Indonesia.

Dietrich, Andreas dan Gabrielle Wanzenried. 2010. Determinants of Bank Profitability Before and During the Crisis: Evidence from Switzerland. Retrieved (https://ssrn.com/abstract=1370245).

Fraser, Lyn M. dan Allen Ormiston. 2004. Memahami Laporan Keuangan. Jakarta: PT Indeks.

Hakim, Luqman dan Sugianto Sugianto. 2018. Determinant Profitability and Implications on the Value of the Company: Empirical Study on Banking Industry in IDX. International Journal of Economics and Financial Issues. Vol. 8 No. 1. Hal: 205-216.

Haneef, Shahbaz, Tabassum Riaz, Muhammad Ramzan, Mansoor Ali Rana, Hafiz Muhammad Ishaq, dan Yasir Karim. 2012. Impact of Risk Management on Non-Performing Loans and Profitability of Banking Sector of Pakistan. International Journal of Business and Social Science. Vol. 3 No. 7. Hal: 307-315.

Hantono. 2017. Effect of Capital Adequacy Ratio (CAR), Loan to Deposit Ratio (LDR) and Non Performing Loan (NPL) to Return On Assets (ROA) Listed in Banking in Indonesia Stock Exchange. International Journal of Education and Research. Vol. 5 No. 1 Hal: 69-80.

Hapsari, Ira. 2018. Moderating Role of Size in the Effect of Loan to Deposit Ratio and Non Performing Loan toward Banking Financial Performance. Prosiding International Conference on Community Development (AMCA 2018), Hal: 351-354

Harahap, Sofyan Syafri. 2016. Analisis Kritis Laporan Keuangan. Jakarta: Rajawali Pers.

Harmono. 2015. Manajemen Keuangan Berbasis Balances Scorecard Pendekatan Teori, Kasus, dan Riset Bisnis. Jakarta: Bumi Aksara.

Husnan, Suad. 2009. Dasar-Dasar Teori Portofolio dan Analisis Sekuritas Edisi Empat. Yogyakarta: UPP STIM YPKN.

Irmawati dan Dewi Kartika Sari. 2014. Analisis Pengaruh Capital Adequacy Ratio (CAR), Loan To Deposit Ratio (LDR) dan Net Interest Margin (NIM) terhadap Return On Asset (ROA) (Studi Kasus pada PT Bank Mandiri (Persero) Tbk Periode 2008-2012. BENEFIT Jurnal Manajemen dan Bisnis. Vol.18 No. 1 Hal: 5-13.

Juliandi, Azuar, Irfan, dan Saprinal Manurung. 2015. Metodologi Penelitian Bisnis Konsep dan Aplikasi. Medan: UMSU Press.

Julita. 2011. Pengaruh Non Performing Loan (NPL) dan Capital Adequacy Ratio (CAR) terhadap Profitabilitas (ROA) pada Perusahaan Perbankan yang Terdaftar di BEI. Kumpulan Jurnal Dosen Universitas Muhammadiyah Sumatera Utara, Vol. 1 No. 1.

Jumingan. 2018. Analisis Laporan Keuangan. Jakarta: Rajawali Pers.

Juwita, Syinta, Panji Dewa Jayeng Raga, Faiz Irsyad Prasetyo, dan Erry Rimawan. 2018. Effect of CAR (Capital Adequacy Ratio), BOPO (Operational Costs on Operational Revenues) and LDR (Loan to Deposit Ratio) to ROA (Return on Assets) PD Bank Pasar Bogor City. International Journal of Innovative Science and Research Technology. Vol.3 No. 6. Hal: 305-309. 
Kaaya, Indiael dan Dickson Pastory. 2013. Credit Risk and Commercial Banks Performance in Tanzania: a Panel Data Analysis. Research Journal of Finance and Accounting. Vol.4, No.16. Hal:55-62.

Karim, Mohd Zaini Abd, Sok-Gee Chan, dan Sallahudin Hassan. 2010. Bank Efficiency and NonPerforming Loans: Evidence from Malaysia and Singapore. Prague Economic Papers. Vol. 2. Hal: 118-32.

Kasmir. 2010. Pengantar Manajemen Keuangan. Jakarta: Kencana Prenada Media Grup. . 2012. Analisis Laporan Keuangan. Jakarta: Rajawali Pers.

Kithinji, Angela M. 2010. Credit Risk Management and Profitability of Commercial Banks in Kenya. School of Business, University of Nairobi.

Kuncoro, Mudrajad dan Suhardjono. 2011. Manajemen PerBankan. Yogyakarta: BPFE.

Kusmayadi, Dedi. 2018. Analysis of Effect of Capital Adequacy Ratio, Loan to Deposit Ratio, Non Performing Loan, Bopo, and Size on Return on Assets in Rural Banks at Indonesia. Saudi Journal of Business and Management Studies (SJBMS). Vol. 3 No. 7 Hal: 786-795.

Latifah, Nurul Maulidya, Rodhiyah, dan Saryadi. 2012. Pengaruh Capital Adequacy Ratio (CAR), Non Performing Loan (NPL) dan Loan To Deposit Ratio (LDR) terhadap Return On Asset (ROA) (Studi Kasus pada Bank Umum Swasta Nasional Devisa Go Public di Bursa Efek Indonesia Periode 2009-2010). Jurnal Ilmu Administrasi Bisnis. Vol. 1 No. 1. Hal: 1-9.

Munawir, S. 2018. Analisa Laporan Keuangan. Yogyakarta: Liberty.

Muttaqin, H. F. 2017. Pengaruh CAR, BOPO, NPL dan LDR terhadap ROA pada Bank Konvensional di Indonesia. E-Jurnal Administrasi Bisnis Unmul.Vol. 5 No. 4.

Paramarta, Wayan Arya dan Ni Luh Gede Emi Suardani. 2014. Capital Adequacy Ratio (CAR), Loan to Deposit Ratio (LDR), Non Performing Loan (NPL) dan Biaya Operasional Pendapatan Operasional (BOPO) yang Berimplikasi terhadap Return on Asset (ROA) pada PT. Bank Rakyat Indonesia (Persero), Tbk. Jurnal Manajemen \& Akuntansi STIE Triatma Mulya. Vol. 20 No. 2. Hal: $127-51$.

Parul, K. 2012. Managing Non-Performing Assets in Commercial Banks. GianJyoti E-Journal. Vol. 1 No. 3 Hal: 22-35.

Pinasti, Wildan Farhat dan RR. Indah Mustikawati. 2018. Pengaruh CAR, BOPO, NPL, NIM dan LDR terhadap Profitabilitas Bank Umum Periode 2011-2015. Jurnal Nominal. Vol. 7 No. 1. Hal: $126-42$.

Pratiwi, Widya, Nanang Al Hidayat, dan Muhammad Nasir. 2018. Pengaruh Non Performing Loan (NPL) terhadap Return On Asset (ROA) (Studi Pada Koperasi Nusantara KCP Muara Bungo). Jurnal Administrasi Sosial Dan Humaniora (JASIORA). Vol. 3 No. 1 Hal: 68-75.

Putrianingsih, Dwi Indah dan Arief Yulianto. 2016. Pengaruh Non Performing Loan (NPL) dan Capital Adequacy Ratio (CAR) terhadap Profitabilitas (Studi Kasus pada Perusahaan Perbankan yang Terdaftar di BEI Periode 2010-2013). Management Analysis Journal. Vol. 5 No. 2. Hal: 110-15.

Simanjuntak, Jontro. 2016. Pengaruh Capital Adequacy Ratio (CAR), Loan to Deposit Ratio (LDR) dan Non Performing Loan (NPL) terhadap Return On Assets (ROA) pada Sektor Perbankan di Bursa Efek Indonesia. BISMAN: Jurnal Bisnis \& Manajemen. Vol. 2 No. 2 Hal: 102-11.

Soares, Pedro dan Muhammad Yunanto. 2018. Pedro Soares The Effect of NPL, CAR, LDR, OER and NIM To Banking Return on Asset. International Journal of Economics, Commerce and Management. Vol. 6 No. 3. Hal:40-55.

Soedarmono, Wahyoe, Fouad Machrouh, dan Amine Tarazi. 2013. Bank Competition, Crisis and Risk Taking: Evidence from Emerging Markets in Asia. Journal of International Financial Markets, Institutions and Money. Vol. 23 Hal :196-221.

Susilowati, Eko Meiningsih dan Erna Tiningrum. 2019. Tata Kelola PerBankan Ditinjau dari Kinerja Keuangan dilihat dari Profitabilitas Perbankan. ProBank: Jurnal Ekonomi dan PerBankan Vol. 4 No. 1. Hal: 9-14.

Usman, B. 2003. Analisis Rasio Keuangan dalam Memprediksi Perubahan Laba pada Bank-Bank di Indonesia. Media Riset Bisnis dan Manajemen. Vol. 3 No. 1 Hal: 59-74.

Veithzal, Arifiandy Permata, Sarwono Sudarto, Sofyan Basir, dan Veithzal Rivai. 2013. Commercial Bank Management Manajemen Perbankan. Jakarta: Rajawali Pers.

Vernanda, Shinta Dewi dan Endang Tri Widyarti. 2016. Analisis Pengaruh CAR, LDR, NPL, BOPO, 
dan SIZE terhadap ROA (Studi pada Bank Umum Konvensional yang Terdaftar di Bursa Efek Indonesia Periode 2010-2015). Diponegoro Journal of Management. Vol. 5 No. 3. Hal: 1-13.

Winarso, Eddy dan Imhmed Abdulgader Salim. 2017. The Influence of Risk Management to the Return on Asset (ROA) Banking Sector (Case Study of Bank in Indonesia Listed in Indonesia Stock Exchange). Advances in Economics and Business. Vol. 5 No. 7. Hal: 382-93.

Yogianta, Catur Wahyu Endra. 2013. Analisis Pengaruh CAR, NIM, LDR, NPL dan BOPO terhadap Profitabilitas Studi pada Bank Umum yang Go Publik di Bursa Efek Indonesia Periode Tahun 2002-2010. Jurnal Bisnis STRATEGI. Vol. 22 No. 2. Hal: 94-111.

Zulfachri, Budi. 2017. Pengaruh Antara Rasio Kecukupan Modal (CAR), Loan To Deposit Ratio (LDR), dan Rasio Biaya Operasional Pendapatan Operasional (BOPO) terhadap Kinerja Profitabilitas Industri PerBankan. Jurnal Manajemen dan Keuangan. Vol. 6 No. 2. Hal: 740 48. 